\title{
Accountability Styles in State-Owned enterprises: The good, the bad, the ugly ... And the pretty
}

\author{
Sonia Royo ${ }^{a}$, Ana Yetano, Javier García-Lacalle \\ Dpt. Accounting and Finance, Faculty of Economics and Business, University of Zaragoza, Spain
}

\footnotetext{
${ }^{a}$ Corresponding author.
}

E-mail address: sroyo@unizar.es

\section{A R T I C LE IN F O}

\section{Article history:}

Received 12 July 2018

Accepted 12 Dec 2018

Available online 1 July 2019

\section{JEL classification:}

G34

L32

M14

M48

O38

Keywords:

Accountability styles

State-Owned Enterprises (SOEs)

e-disclosure

\begin{abstract}
A B S T R A C T
Ensuring public access to the information that State-Owned Enterprises (SOEs) produce is necessary and corporate websites should be used for this purpose. However, there is a lack of research analyzing the ac countability of SOEs. This paper aims to identify different accountability patterns among SOEs by carrying out an assessment of the e-disclosure levels of Spanish SOEs. For this purpose, a comprehensive website content analysis of 91 SOEs owned by the Spanish central government was carried out. Each website was analyzed for 60 items classified into 4 dimensions: 1) financial information, 2) information about objectives and strategies, 3) corporate governance and 4) usability. In order to identify different accountability patterns among SOEs, cluster, multidimensional scaling and Pro-Fit analyses were carried out. Results show that e-disclosure practices among Spanish SOEs are still in their infancy. Financial accountability is the main focus of SOEs disclosures and most are silent about their policies, objectives and corporate governance structures. The majority of them are still anchored in a narrow accountability style that only considers shareholders as the key stakeholders and they are a long way from fulfilling the OECD recommendation that they should be as transparent as listed companies. Furthermore, results show that enforcement of transparency-related legislation is scarce in Spain. Based on these findings, some recommendations to improve e-disclosure practices among SOEs are suggested.
\end{abstract}

(C)2019 ASEPUC. Published by EDITUM - Universidad de Murcia. This is an open access article under the CC BY-NC-ND license (http://creativecommons.org/licenses/by-nc-nd/4.0/).

Estilos de rendición de cuentas en empresas públicas: el bueno, el malo, el feo ... y la guapa

R E S U M E N

Garantizar el acceso del público a la información que generan las Empresas Públicas (EP) es necesario y las páginas web corporativas deberían utilizarse para lograr este objetivo. Sin embargo, no existen estudios académicos que analicen la rendición de cuentas por parte de las EP. Este trabajo pretende identificar diferentes estilos de rendición de cuentas en las EP, llevando a cabo una evaluación de los niveles de divulgación a través de Internet de las EP españolas. Para lograr este objetivo, se ha llevado a cabo un análisis de $91 \mathrm{EP}$ de titularidad estatal. En cada página web se ha analizado la presencia de 60 atributos clasificados en 4 dimensiones: 1) información financiera, 2) información sobre objetivos y estrategias, 3) gobierno corporativo y 4) facilidad de uso. Para identificar los diferentes estilos de rendición de cuentas se han utilizado análisis cluster, escalas multidimensionales y Pro-Fit. Los resultados muestran que las prácticas de divulgación de información a través de Internet de las EP españolas todavía se encuentran muy poco desarrolladas. La rendición de cuentas de tipo financiero ocupa el principal foco de atención de las EP y en su mayoría no divulgan información sobre sus políticas, objetivos y estructuras de gobierno corporativo. La mayor parte están ancladas en un estilo limitado de rendición de cuentas que solo considera a los accionistas como principales agentes interesados y lejos de cumplir la recomendación de la OCDE de ser tan transparentes como las empresas cotizadas. Además, los resultados muestran que el cumplimiento de la legislación en materia de transparencia es escaso. Sobre la base de estos resultados, se sugieren algunas recomendaciones para mejorar las prácticas de divulgación de información a través de Internet en las EP.

C2019 ASEPUC. Publicado por EDITUM - Universidad de Murcia. Este es un artículo Open Access bajo la licencia CC BY-NC-ND (http://creativecommons.org/licenses/by-nc-nd/4.0/). 


\section{Introduction}

Despite the trend toward privatization in recent decades, State-Owned Enterprises (SOEs) ${ }^{1}$ are still significant economic players (European Commission, 2016; Grossi, PapenfuSS, \& Tremblay, 2015; World Bank, 2014). They account for around $10 \%$ of the global gross domestic product (Bruton, Peng, Ahlstrom, Stan, \& Xu, 2015). According to Florio, Ferraris, and Vandome (2018), the world's 2,000 largest SOEs employ more than 6 million people, their operating revenues make up $19 \%$ of international trade and their total sales represent $6 \%$ of the world's gross national income. Although their importance is lower than in the past in a number of countries which have undertaken significant privatization programs since the 80 s, such as Spain, SOEs are still relevant in these countries. They are prevalent in public services of general economic and social interest (see OECD, 2005a, 2017), whose performance is of great importance to broad segments of the population. Furthermore, substantial public expenditure is usually allocated to these organizations (Alexius \& Cisneros, 2015). As good governance of SOEs is critical to ensure their positive contribution to economic efficiency and competitiveness (Grossi et al., 2015; OECD, 2015b; Rygh, 2018), requirements and pressure for effectiveness, efficiency, sustainability and transparency in SOEs are increasing (Grossi et al., 2015; World Bank, 2014).

SOEs manage public money and pursue social goals that coexist with economic objectives (Allini, Manes Rossi, \& Hussainey, 2016). They are frequently referred to as hybrid organizations because they operate in a business-like manner to provide public services with public funding and are politically governed (Grossi et al., 2015). This duality of public and private elements raises important questions, such as to what extent they use public or private accountability styles. It has been argued that hybridity produces new or, at least, different accountability regimes. SOEs have to address multiple information needs that may create difficulties because they must achieve the objectives of private sector corporate governance, focused on the relationship between a for-profit organization and its shareholders, as well as public sector accountability, particularly downward accountability to citizens as taxpayers demanding adequate delivery of value for money (Greiling, Traxler, \& Stötzer, 2015; Shaoul, Stafford, \& Stapleton, 2012; Swiatczak, Morner, \& Finkbeiner, 2015). In fact, SOEs are expected to provide even more non-financial information (e.g. achievement of objectives) and corporate responsibility disclosures (e.g. social and environmental information) than private firms because of the need for the legitimation of their existence and actions (Greiling et al., 2015; OECD, 2016; van der Laan Smith, Adhikari, \& Tondkar, 2005). As a result, transparency and disclosure are more important for SOEs than for other companies; they have to show that political control is being exercised at arm's length and make their goals clear to citizens (OECD, 2005a). The organization Transparency International has highlighted accountability through transparency and disclosure as one of the ten principles to fight against corruption in SOEs (Wilkinson, 2017).

Transparency and e-disclosure are key elements to facilitate the monitoring of whether SOEs are fulfilling their ob-

\footnotetext{
${ }^{1}$ For the purposes of this paper, SOEs are defined as any corporate entity recognized by national law as an enterprise (e.g., joint stock companies, limited liability companies or partnerships limited by shares) and in which the central level of government exercises ownership and control (direct or indirect participation or voting rights higher than 50\%). The definition of SOEs often includes corporations owned by local and regional levels of government, but our focus is central government ownership.
}

jectives and crucial to holding SOEs accountable for their performance. Exposing processes and performance to public scrutiny provides strong incentives for good management (Cameron, 2004; Cucciniello, Porumbescu, \& Grimmelikhuijsen, 2017; Hood \& Heald, 2006; IIRC, 2016; OECD, 2005a; Spá, Voda, \& Zagrapan, 2018). An effective reporting regime requires SOEs to abide by the same reporting, control, and audit frameworks as other significant corporate or public interest entities and to disclose both financial and nonfinancial information (Alexius \& Cisneros, 2015; IIRC, 2016; Ntim, Soobaroyen, \& Broad, 2017; OECD, 2005b 2015b; Wilkinson, 2017; World Bank, 2014). Ensuring public access to the information that SOEs produce is necessary and corporate websites should be used for this purpose. However, there is a lack of research analyzing the accountability of SOEs (Daiser, Ysa, \& Schmitt, 2017; Grossi et al., 2015).

In this context, the objective of this paper is to identify different accountability patterns among SOEs by carrying out an assessment of the e-disclosure levels of Spanish SOEs. Spanish SOEs have been chosen because of the strong impact of the economic crisis in Spain and because of the corruption scandals that have increased citizen demand for public financial accountability (see ICAEW, 2014). Furthermore, the Transparency Act (Government of Spain, 2013) has required SOEs to disclose institutional and financial information on the Internet since the end of 2014. According to Bonsón and Flores-Muñoz (2014), an entity is more likely to disclose information if there is an obligation (to comply with regulation), a financial necessity (to reduce its cost of capital) and/or social pressure (from stakeholders). A priori, all these factors come together in the Spanish public sector today. The results of this study are particularly useful to policymakers and standard-setters concerned with public sector governance and the enforcement of corporate governance codes as regards transparency and disclosure. Results suggest that more efforts are needed to guarantee citizen access to SOEs' information and the enforcement of transparencyrelated codes and legislation.

\section{Downward accountability in SOEs: transparency, inter- activity and stakeholder orientation}

In SOEs, ownership is exercised by government officials on behalf of the general public. Governance issues in SOEs (Bruton et al., 2015; Grossi et al., 2015; OECD, 2015b; World Bank, 2014) include complicated and, at times, contradictory mandates, the absence of clearly identifiable owners, passive or distant oversight by the state as owner, politicized boards and management, lack of autonomy in day-to-day operational decision making, weak financial reporting and disclosure practices, and insufficient performance monitoring and accountability systems. Where these shortcomings are more common, SOEs may also be a source of corruption. As an answer to these common problems, the OECD (2005b) issued its Guidelines on Corporate Governance of SOEs (updated in 2015), recommending that SOEs should observe high standards of transparency, disclosing both financial and non-financial information, and that, in the interest of the general public, they should be as transparent as listed companies, if not more so, in order to fulfill both upward and downward accountability.

Accountability is considered a necessary condition for preserving democracy and facilitating good governance as well as a mechanism to improve SOEs management. Accountability can have many different meanings or dimensions in the public sector (Luke, 2010). The distinction between the 
traditional "upward accountability" and "public accountability" or "downward accountability" (Heald, 2006; Luke, 2010) is very important because the former does not imply that the accountability process will be visible to outside parties and tends to involve pre-determined actors/parties, potentially excluding larger constituencies (see Ntim et al., 2017). Within the public sector, accountability to Parliament has traditionally been the only focus, especially in Continental and Southern Europe. Legislation and regulatory frameworks governing SOEs commonly provide clear details of accountability in a traditional (upward) context (Luke, 2010).

Downward accountability is often defined as the answerability of government to the public on its performance (Behn, 2001; Bovens, Schillemans, \& Hart, 2008; Wong \& Welch, 2004). The extent to which an organization provides comprehensive information about its attributes (transparency) and maintains timely communications with its various publics (interactivity) has been considered a measure of government accountability (Pina, Torres, \& Royo, 2010; Wong \& Welch, 2004). It is a sine qua non of modern democracies that the public can and should scrutinize public expenditure as part of the accountability process (Shaoul et al., 2012). Therefore, downward accountability should be exercised in an open forum and organizations/managers should be expected to make all information available for public scrutiny. However, public sector reporting has been criticized because accountability mechanisms have tended to focus on upward accountability to funders rather than on downward accountability to citizens (Collier, 2008). This has started to change in recent decades because of a greater focus on the consideration of ethics in public management, the widespread adoption of freedom of information acts and the use of ICTs.

In recent decades, accountability mechanisms have been blossoming in the context of a severe crisis of legitimacy for democracies (Célérier \& Cuenca-Botey, 2015). Public expectations as regards transparency and accountability have increased considerably because of advances in ICTs. As accountability depends upon the free flow of appropriate information (Cameron, 2004; Mulgan, 2000), the diffusion of information through the corporate websites becomes crucial for accountability to be a reality. Accountability using new technologies helps citizens to perceive governments as accessible, transparent, responsible, effective and participative (Tolbert \& Mossberger, 2006). However, downward accountability seems to be a pending issue. Smith, Mathur, and Skelcher (2006) argue that there is certainly strong upward accountability for spending and nationally set targets, but what is missing is public oversight - the ability of the community to hold hybrid organizations to account for their actions. As shown by Smith et al., (2006) and Shaoul et al., (2012), there may be a democratic deficit exhibited by hybrid organizations in relation to accountability to citizens.

This paper focuses on transparency and the e-disclosures that are needed for SOEs to render accountability to citizens $\left(\right.$ downward transparency ${ }^{2}$ ). As other authors do (Heald, 2006; Luke, 2010; Mulgan, 2000; Shaoul et al., 2012), we recognize that accountability may have wide-ranging meanings and that it may be achieved in many different ways. We focus on the disclosure of financial, non-financial and corporate governance information. Furthermore, the literature has acknowledged that the mere disclosure of information is not

\footnotetext{
${ }^{2}$ By downward transparency, Heald (2006, p. 27) refers to the possibility of those "ruled" to observe the conduct, behavior and/or results of their rulers. In the SOE context, downward transparency refers to the possibility of any interested party to have access to comprehensive information about the SOE, subject to the requirements of commercial confidentiality, security, data and privacy laws (Wilkinson, 2017).
}

enough and that stakeholder orientation (or responsiveness) is necessary for effective accountability (Cohen, Mamakou, \& Karatzimas, 2017; Cucciniello, Bellè, Nasi, \& Valotti, 2015; Shaoul et al., 2012). Therefore, the accessibility to and usability of the information, together with the possibility of citizens contacting SOEs to ask for transparency-related information, have also been considered in this research. In the next section, we propose a theoretical framework to explain the different types of e-disclosures that SOEs can carry out and that also includes the above mentioned features (accessibility, usability and citizen dialogue) that promote public accountability.

\section{Theoretical framework}

The ideas of transparency and accountability are most often rendered normatively in terms of principals and agents (agency theory). However, the ability of any single theoretical framework to explain e-disclosure practices is limited, justifying the use of a multi-theoretical framework (Ntim et al., 2017). A gradual incorporation of a wider set of social, political and institutional-led motivations in the voluntary and e-disclosure literature has taken place recently in order to complement or supersede the mainstream agency theory perspective by including insights from legitimacy, resource dependence, institutional and/or stakeholder theories, among others (Bonsón \& Bednárová, 2015; Brennan \& Solomon, 2008; Cormier, Magnan, \& Van Velthoven, 2005; Gallego-Álvarez \& Quina-Custodio, 2016; Greiling et al., 2015; Ntim et al., 2017; Pina et al., 2010). A common thread from these perspectives is that disclosure serves a broader and more complex purpose in the organization's interactions with its environment than the narrow, wealth maximizing and rational actor logic that underpins agency theory (Cormier et al., 2005; Ntim et al., 2017). This has been made evident by the adoption of social missions by private and public sector entities in the wake of the corporate social responsibility (CSR) and sustainability movements (Alexius \& Cisneros, 2015; Bonsón \& Bednárová, 2015; Greiling et al., 2015). It is even clearer when considering hybrid organizations where accountability for "performance" is inherently multi-faceted (i.e. towards beneficiaries, government and/or other shareholders, the public, staff, suppliers...) and not primarily driven, or measured, by financial distributions to providers of capital.

As some of the theories listed above show a certain degree of overlap, this study focuses on legitimacy and stakeholder theories to complement agency theory in order to explain the type of information being disclosed through SOEs' corporate websites. The basic difference between legitimacy and stakeholder theory resides in the breadth of the plural concept of stakeholders. Whereas legitimacy theory assumes that information must be addressed to society at large, stakeholder theory accepts the existence of different interest groups with different ideas as to how the firm can best act, and with different capabilities for influencing organizational activity (Deegan, 2002, p. 294). As shown in Figure 1 , our framework recognizes that SOEs may take a narrow approach to accountability, by focusing on financial information as the main interest of shareholders (agency theory point of view) or a broader approach that considers the interest of multiple stakeholders (legitimacy/stakeholder theories), by adding non-financial information and other elements to facilitate public accountability.

Agency theory has traditionally been used for justifying 
Figure 1

Theoretical framework for e-disclosure in SOEs

\begin{tabular}{|c|c|}
\hline \multirow{4}{*}{$\begin{array}{c}\text { NARROW APPROACH } \\
\text { (Shareholders) } \\
\text { Agency Theory } \\
>\text { Financial information }\end{array}$} & $\begin{array}{c}\text { BROADER APPROACH } \\
\text { (Multiple interests) }\end{array}$ \\
\hline & Legitimacy / Stakeholder Theories \\
\hline & \\
\hline & $>$ Financial information \\
\hline & $\begin{array}{l}\text { Non-financial information (objectives, policies, CSR, } \\
\text { corporate governance information...) }\end{array}$ \\
\hline & $\begin{array}{l}\text { Exemplification of responsibility (conformance to } \\
\text { legal demands, adoption of best practices and } \\
\text { conformance to professional standards) }\end{array}$ \\
\hline & Public Accountability \\
\hline & $\begin{array}{l}\text { Usability, accessibility, timeliness, understandability, } \\
\text { citizen dialogue }\end{array}$ \\
\hline
\end{tabular}

Source: Own elaboration

accountability practices and requirements. A central insight of this theory is that those who rule may not have identical interests to those that it is their responsibility to serve (moral hazard), and that they must account for their actions to demonstrate they have acted in line with their responsibilities. Accountability for SOEs involves a complex chain of agents (management, board, ownership entities, ministries, the government and the legislature), in which the principals are not easily identifiable or are remote. Therefore, this can potentially be a fertile ground for insiders to motivate decisions based on criteria other than the best interests of the enterprise and the general public. The ability of the principal to curb opportunistic behavior depends on how much information it has about the performance of the agent. Therefore, agency theory points to greater disclosure as the way to mitigate information asymmetry and to reduce moral hazard and agency costs. Greater disclosure also enables the principal to exercise ex-post assessment of the dual role (agent/principal) played by the state shareholder (Allini et al., 2016). Therefore, agency theory explains the increasing presence of legislation requiring greater information disclosures because organizations do not usually report on a voluntary basis.

The disclosure of accounting information has always been closely linked to the agency problem, since accounting has the primary function of producing information for external users who have no access to internal information. Agency theory envisages disclosure as useful to assist users in making assessments and decisions regarding financial issues, e.g. investing or divesting, monitoring managerial performance and actions, ensuring contractual commitments are met, and assessing risk (Ntim et al., 2017). In particular, agency theory posits that disclosure is a means to reduce information asymmetry between contractually related partners. Under this perspective, shareholders are considered as the dominant stakeholder group and protecting and enhancing shareholder wealth is a major concern (Brennan \& Solomon, 2008). As such, downward accountability to citizens may not be considered as important as upward accountability in the SOEs context. Furthermore, Shaoul et al., (2012) raise the question of whether a system based on market mechanisms is sufficient to ensure accountability in hybrid organizations which are subject to public sector values (Grossi \& Thomasson, 2015). Thus, the governance issues faced by SOEs are slightly different to those of private firms, and their accountability should reflect the needs of multiple principal stakeholders.

Legitimacy theory conceives the organization as a social contract which links societal interests with business interests. The basic concept of this theory is that organizations aim to match their value systems with the values of the larger so- cial system to which the entity belongs (Greiling et al., 2015; Ntim et al., 2017). According to Suchman (1995, p. 574), "legitimacy is a generalized perception or assumption that the actions of an entity are desirable, proper, or appropriate within some socially constructed system of norms, values, beliefs, and definitions". Therefore, legitimacy theory provides a societal-led motivation for voluntary disclosure. In general, larger public sector organizations face greater legitimation needs caused by their higher visibility and influence (Greiling et al., 2015). Organizations, such as SOEs, can only survive if their activities and objectives are supported by society and, as such, perceived to be legitimate. Voluntary disclosures are a building block of this theory (Deegan, 2002; Suchman, 1995); they are desirable by themselves, in that they are appropriate actions deemed to be "expected" of a "professional and well-structured" organization. Within such a perspective, voluntary disclosures might well be ritualistic and symbolic in nature, with the aim of improving the firm's image (e.g, if the legitimacy of the organization is threatened as a result of a particular event, the organization will adopt different strategies to restore its legitimacy). Previous studies have shown that the search for legitimacy usually leads to the disclosure of information that requires the lowest efforts rather than promoting substantial changes in government-tocitizen relationships (Pina et al., 2010; Pina, Torres, \& Yetano, 2009).

Suchman (1995, p. 589 and 600) breaks down legitimacy into three broad types: pragmatic (conforming to demands), moral (conforming to ideals or adoption of best practices) and cognitive (conforming to established/professional models or standards, as a way to demonstrate that the organization has characteristics that are intrinsically worthy). As explained in the methodology section, this typology has been adapted to classify the different types of disclosures made by SOEs. This distinction between mandatory (pragmatic) and discretionary (moral and cognitive) disclosures should be useful to preserve a level of uniformity whilst simultaneously allowing organizations to adapt e-disclosure to their specific circumstances (Chiwamit, Modell, \& Scapens, 2017). Cognitive legitimacy becomes most significant in the absence of clear outcome measures. According to Oliver (2004, p. 37), "transparency in an organization is not only about what's communicated externally, but about what's right on the inside, in the guts of its operations". As suggested by Meyer and Rowan (1977), structures and procedures often serve as easily monitored proxies for less visible targets of evaluation, such as outcomes.

\section{Stakeholder theory}

Stakeholder theory (Freeman, 1984) is concerned with the relationships of an organization with a variety of relevant groups of stakeholders in society, rather than society at large. A stakeholder is "a person or group that can affect or is affected by the achievement of the organization's objectives" (Freeman, 1984 p. 46). Therefore, stakeholder theory places a great deal of emphasis on the identification and management of key interest groups. The stakeholder concept is intended to "broaden management's vision of its roles and responsibilities beyond the profit maximization functions to include interests and claims of non-stockholding groups" (Mitchell, Agle, \& Wood, 1997 p. 855). Shareholders are, of course, a substantial class among stakeholders, but other audiences, such as customers, suppliers, employees, local communities, regulators, the media or the general public, may also be important. From a normative point of view, stakeholder theory 
sets out that organizations have to recognize the multiple expectations of their different stakeholders and that it is their duty to provide a full and transparent account of their activities to a wider audience. In this line, stakeholder theory highlights that corporate accountability should move beyond simple economic or financial performance (Mitchell et al., 1997) because the long-term survival and success of the corporation requires the support of all its stakeholders and gaining this support and approval requires a dialogue between the management of a corporation and its stakeholders (van der Laan Smith et al., 2005, p. 127). Previous research has noted that code law countries have a higher stakeholder orientation whereas shareholder orientation seems to be more important in common law countries (Ball, Kothari, \& Robin, 2000), which could potentially influence non-financial corporate disclosures (see van der Laan Smith et al., 2005).

In comparison with private sector entities, public sector organizations are accountable to a larger variety of stakeholders with less clear prioritization mechanisms and hierarchies (Greiling et al., 2015). As regards the role of the general public within this theoretical framework, the literature investigating the normative aspects of this theory views citizens as equal to the rest of the key stakeholders, with legitimate interests driven by philosophical concepts such as moral ethics, the common good, freedom, fairness and justice (Yekini, Adelopo, Andrikopoulos, \& Yekini, 2015, p. 253). However, the literature acknowledges that, very often, variability in the disclosure themes may be due to an instrumental form of stakeholder theory, whereby organizations may strategically orient their voluntary disclosures to target and manage their most important stakeholder(s) (Ntim et al., 2017; Pérez, López, \& García-De los Salmones, 2017).

Mitchell et al. (1997) argue that managers' behavior towards stakeholders' demands will not only vary according to the legitimacy of the different stakeholders, but also according to their urgency and power. When there is legitimacy but not power and urgency, there is no pressure on managers to engage in an active relationship with such stakeholders, although managers can choose to do so. This may explain that, normally, financial and non-financial disclosures are not widely adopted until mandatory requirements are established. The international recognition of transparency and disclosure as tools to improve trust and legitimacy in SOEs (OECD, 2005b 2015b; Wilkinson, 2017; World Bank, 2014) and the recent enactment of legislation requiring public sector transparency could be interpreted by SOEs' managers as urgency. As we move to a situation of dependency (where there is urgency and the stakeholders are legitimate, but have no power) citizens will depend upon others (other stakeholders or the managers) for the power necessary to satisfy their needs (see Mitchell et al., 1997). As has been argued, public sector relationships between the agents (managers) and principals (citizens) are complex, open-ended, not explicitly defined and, thus, not easily monitored (Broadbent \& Laughlin, 2003; Letza, Smallman, \& Sun, 2004). Thus, citizens become legitimate stakeholders with the urgency of the public sector reform, although they depend on the power of other stakeholders to make SOEs' transparency a pursued goal. Therefore, according to stakeholder theory, the level of disclosure, in particular for voluntary information, will reflect to what extent SOEs feel under pressure to legitimate their actions through greater levels of disclosure.

\section{Spanish context}

In Spain, as in other Southern European countries such as Italy (see Allini et al., 2016), SOEs were mainly created as a result of either market failure, socio-political factors or a combination of both. Nowadays, the size of the public enterprise sector at central level in Spain has decreased (European Commission, 2016, p. 8 and 12) due to the privatization process that started in the early 80s (Bachiller, 2009) and to a second wave of reforms that has affected agencies, foundations, SOEs and other governmental entities since the financial crisis. Even so, Spanish SOEs owned by the central government have a turnover of 25,000 million euros $(2.3 \%$ of the Spanish GDP), manage assets worth 227,000 million euros ( $22 \%$ of Spanish GDP) and employ 140,000 people Transparency International Spain, 2018.

The privatization of Spanish SOEs that started in the 80s occurred for three basic reasons (Cabeza \& Gómez, 2007): 1 ) the economic crisis of the late 70s and early 80s; 2) the need to adjust Spanish industry to the new economic environment being ushered in by Spain joining the European Community in 1986; and 3) the reaction to the opening-up of international markets. As a result, 134 SOEs from almost every industry (including strategic industries such as telecommunications, energy, transport and banking) were privatized between 1985 and 2004 as part of a process of economic restructuring founded upon liberalization and deregulation (Cabeza \& Gómez, 2007). However, the main arguments for privatizations in Spain were not based on the assumed superior efficiency of private ownership, but on the reduction of deficit and public debt and the development of capital markets (Bachiller, 2009).

Since the last financial crisis, reforms in the SOEs sector and the reduction in the number of SOEs have continued at central level, reaching a certain level of stability since 2010. In addition to the reduction in the number of SOEs, there were other reforms oriented to improving their effectiveness and transparency. These reforms included limits to the number of board members and to the salaries of SOEs' managers and members of the governing board. In addition, the Transparency Act (Government of Spain, 2013) has required public sector entities in general to disclose certain information on the Internet since the end of 2014, as explained below.

Channels for the dissemination of information can be as important as the content of the information itself (OECD, 2015a). The availability of certain information related to Spanish SOEs has been greatly enhanced in recent years. For example, SOEs' financial statements and audit reports have been available online since 2004 when the "Public sector annual accounts Registry" was created (nowadays this information can be accessed through the Transparency Portal, http://transparencia.gob.es). Public procurement information has also been available online since 2008 (nowadays, all the information related to the central government and some regional governments can be accessed through https://contrataciondelestado.es). However, citizens do not necessarily know these centralized resources and access to other institutional and governance information is not centralized. Therefore, only individual corporate websites of SOEs have been analyzed in this research. When they included direct links to specific sections in other websites containing the individual information of the SOE under examination, this information has also been considered (that is, when the citizen was transferred seamlessly to information published in other websites).

The Transparency Act (Government of Spain, 2013, art. 6- 
8) requires public sector institutions (including SOEs) to disclose institutional, organizational, planning and economic information through their websites ${ }^{3}$, including: functions, applicable regulations, organizational structure, multi-annual plans and programs, goals and their achievement, financial and budgetary information, audit reports, information related to public procurement and senior managers' retributions, and the necessary statistical information in order to assess to what extent service delivery and quality objectives have been fulfilled. Furthermore, the act states that the information must be published in a clear, structured, understandable and reusable way, but no specific guidelines regarding these aspects are provided.

\section{Methodology}

\section{Sample and data collection}

The sample of SOEs was taken from the Inventory of Public Sector Organizations ${ }^{4}$ that is elaborated on a yearly basis by the Spanish General State Comptroller (IGAE). Data referring to 31 December 2016 resulted in 146 enterprises owned by the Spanish central government. After removing foreign companies, those in liquidation or belonging to the financial sector, the final sample comprises 94 enterprises. No website was found for two of the companies and the website of another company was not available due to the dockers' strike in the first months of 2017. Therefore, 91 SOEs are included in this study. The Appendix provides aggregated background information about the SOEs analyzed. The sector of activity that includes the greatest number of companies is "transportation and storage" (22\%) and most of them are assigned to the Ministry of Finance (57.1\%). 10 (11\%) are parent companies required to prepare both individual and consolidated financial statements, $49(53.8 \%)$ prepare individual annual accounts using the standard format and $32(35.2 \%)$ use the abbreviated format. Most of them (81 companies, 89\%) have a board of directors (BoD). One company, AENA, is listed on the Spanish stock market and subject to additional disclosure regulation under the supervision of the Spanish Stock Exchange Commission (CNMV). This regulation, in terms of content disclosure, is similar to the regulation of other developed markets, such as the United Kingdom.

A comprehensive website content analysis was carried out, between mid-February and mid-March 2017, and each website was analyzed for 60 items (see Table 1). These items were selected based on the Transparency Act requirements explained above, previous studies on internet financial reporting both in the public and the private sector (Caba, Rodriguez, \& López, 2008; Gandia \& Archidona, 2008; Pina et al., 2010) and the Guidelines on Corporate Governance of SOEs (OECD, 2015b). To ensure the quality of the data collected, the following actions were carried out. First, before the data collection, the authors separately analyzed 5 of the websites to check for consistency in the application of the coding criteria ${ }^{5}$. Virtually no scoring differences were found, although some additional clarifications were introduced. All the coding was undertaken by one person with previous knowledge about financial reporting by Spanish SOEs

\footnotetext{
${ }^{3}$ Art. 6 also requires public administrations involved in the rulemaking process to disclose information of legal relevance, but this does not apply to SOEs.

${ }^{4}$ http://www.igae.pap.hacienda.gob.es/sitios/igae/es-ES/BasesDatos/ ClnInvespe/Paginas/invespe.aspx

${ }^{5}$ Because of space requirements, the coding criteria have not been included, but they are available from the authors upon request.
}

and experience in website analysis. Therefore, inter-coder reliability is not a problem in this research. During the data collection, the authors met several times with the coder to resolve possible doubts.

Most items were rated ' 1 ' if they appeared on the website and ' 0 ' if not. Four items were scored ' 0.5 ' if they partially fulfilled the coding criteria (all of them in the corporate governance dimension, items c5, c7, c9 and c10, see Table 1). This method has been applied in similar assessments (Pina et al., 2010; Royo, Yetano, \& Acerete, 2014). Additionally, some items were given no score at all (i.e. treated as a missing data) when they referred to non-applicable information (e.g., consolidated financial statements for those companies not required to prepare consolidated annual accounts). In this way, companies were not penalized for not disclosing non-applicable information.

\section{Dimensions analyzed}

To identify how accountability requirements are fulfilled, the information disclosed in the SOEs' websites was classified on 4 dimensions: 1) financial and economic information, 2) information about objectives, policies and strategies, 3) corporate governance, and 4) usability (see Table 1).

Financial and economic information ("financial", 17 items) assesses the level of disclosure of annual accounts, audit reports, budgetary information and public procurement information, among others. The disclosure of financial information is a key mechanism in the search for transparency and accountability as it ensures that stakeholders can form a reasoned judgement about the financial position, the allocation and use of public funds and public sector management. Several authors consider financial reports as key tools to meet public financial accountability requirements and highlight the need to open financial data to the public. Information about the financial position, financial performance and service performance is crucial to determine the sustainability of service delivery and value for money issues (Chan, 2003; Kopits \& Kraig, 1998; Mack \& Ryan, 2006; Peters, 2007; Pina et al., 2010; Torres, Pina, \& Acerete, 2006). The items in this dimension are information that SOEs are required to prepare by law. Therefore, the disclosure of the items included in this dimension should not represent, a priori, any problem for Spanish SOEs.

Information about objectives, policies and strategies ("policies", 13 items) assesses the level of disclosure of nonfinancial information referring to the SOEs' objectives, organizational structure, and CSR report, as well as policies regarding internal audit, ethical behavior, remuneration, riskmanagement and selection of members of the governing body, among others. SOEs disclosure should cover both financial and non-financial information, reflecting the needs of the multiple stakeholders of these organizations that pursue a social mission through the use of market mechanisms (Alexius \& Cisneros, 2015; Ebrahim, Battilana, \& Mair, 2014; OECD, 2015b; World Bank, 2014). Therefore, information about objectives, policies and strategies and sustainability reports seem particularly helpful for SOE to discharge accountability.

Corporate governance ("corporate", 16 items) includes disclosures about the exercise of power in an entity, that is, how it is directed and controlled (Gandia \& Archidona, 2008; Grossi et al., 2015; Hodges, Wright, \& Keasey, 1996). These include the ownership structure, information about directors and top managers, number of meetings of the BoD, number of committees within the BoD and the publication of a corpor- 
Table 1

Individual items

\begin{tabular}{|c|c|c|c|c|c|c|c|c|c|c|c|}
\hline Item & $(*)$ & Financial and economic information & $\mathbf{n}$ & $\%$ & $\mathbf{N}$ & Item & $(*)$ & $\begin{array}{r}\text { Corporate Governance } \\
\end{array}$ & n & $\%$ & $\mathbf{N}$ \\
\hline f1 & 2 & Operating budget & 11 & $12.1 \%$ & 91 & $\mathrm{c} 1$ & 2 & Corporate governance annual report & 12 & $13.2 \%$ & 91 \\
\hline f2 & 2 & Capital budget & 10 & $11.0 \%$ & 91 & c2 & 2 & SOE's ownership structure & 56 & $61.5 \%$ & 91 \\
\hline f3 & 1 & Balance sheet & 51 & $56.0 \%$ & 91 & c3 & 2 & Regulation on the operation of the $\mathrm{BoD}$ & 16 & $19.8 \%$ & 81 \\
\hline f4 & 1 & Income statement & 51 & $56.0 \%$ & 91 & c4 & 1 & List of members of the governing body & 54 & $59.3 \%$ & 91 \\
\hline f5 & 1 & Statement of cash flows & 38 & $64.4 \%$ & 59 & c5 & 1 & CVs [Only president: 21 ; All members: 10] & & $22.5 \%$ & 91 \\
\hline f6 & 1 & Statement of changes in equity & 48 & $52.7 \%$ & 91 & c6 & 1 & Total remuneration of the members of the governing body & 7 & $7.7 \%$ & 91 \\
\hline f7 & 1 & Notes & 48 & $52.7 \%$ & 91 & c7 & 1 & Individual remunerations [Only president: 24 ; All members:1] & & $16.0 \%$ & 81 \\
\hline f8 & 2 & Management report & 46 & $66.7 \%$ & 69 & $c 8$ & 1 & Top management composition (list of members) & 61 & $67.0 \%$ & 91 \\
\hline f9 & 1 & Audit report & 49 & $59.0 \%$ & 83 & c9 & 1 & CVs [Only CEO: 9; All managers: 33$]$ & & $41.2 \%$ & 91 \\
\hline f10 & 2 & Financial statements signed by directors & 39 & $76.5 \%$ & 51 & c10 & 1 & Individual remunerations [Only CEO: 26; All managers: 5] & & $19.8 \%$ & 91 \\
\hline f11 & 1 & Consolidated financial statements & 6 & $60.0 \%$ & 10 & $\mathrm{c} 11$ & 2 & Status of the directors (executive/non-executive/independent) & 14 & $17.3 \%$ & 81 \\
\hline f12 & 2 & Consolidated management report & 6 & $60.0 \%$ & 10 & $\mathrm{c} 12$ & 2 & Meetings of the BoD & 0 & $0.0 \%$ & 81 \\
\hline f13 & 1 & Consolidated audit report & 6 & $60.0 \%$ & 10 & c13 & 2 & Committees within the BoD & 19 & $23.4 \%$ & 81 \\
\hline f14 & 2 & Consolidated financial statements signed by directors & 2 & $33.3 \%$ & 6 & c14 & 3 & Audit/internal control committee & 26 & $32.1 \%$ & 81 \\
\hline f15 & 1 & Public procurement & 64 & $70.3 \%$ & 91 & c15 & 3 & Risk committee & 4 & $4.9 \%$ & 81 \\
\hline f16 & 2 & Average period of payment to suppliers & 2 & $2.2 \%$ & 91 & c16 & 3 & Nominations and remuneration committee & 2 & $2.5 \%$ & 81 \\
\hline $\mathrm{f} 17$ & 1 & Performance / quality indicators & 32 & $35.2 \%$ & 91 & & & & & & \\
\hline Item & $(*)$ & Objectives, policies and strategies & $\mathbf{n}$ & $\%$ & $\mathbf{N}$ & Item & $(*)$ & Usability & & $\%$ & $\mathbf{N}$ \\
\hline $\mathrm{p} 1$ & 2 & Articles of association & 28 & $30.8 \%$ & 91 & u1 & 2 & Link to the Transparency/CG section in the homepage & 73 & $80.2 \%$ & 91 \\
\hline p2 & 1 & Organization chart & 60 & $65.9 \%$ & 91 & u2 & 2 & Website map & 46 & $50.5 \%$ & 91 \\
\hline p3 & 3 & Internal audit department / internal audit procedures & 12 & $13.2 \%$ & 91 & u3 & 2 & Internal search engine & 51 & $56.0 \%$ & 91 \\
\hline $\mathrm{p} 4$ & 2 & SOE's objectives (mission, vision, values) & 29 & $31.9 \%$ & 91 & u4 & 2 & No broken links & 75 & $82.4 \%$ & 91 \\
\hline p5 & 3 & Annual objectives with defined indicators & 2 & $2.2 \%$ & 91 & u5 & 2 & E-mail alerts / RSS & 15 & $16.5 \%$ & 91 \\
\hline p6 & 3 & Code of conduct/ethical code/good governance code & 37 & $40.7 \%$ & 91 & u6 & 1 & Ease of management of the reports (searchable pdf) & 17 & $27.4 \%$ & 62 \\
\hline p7 & 3 & Fraud prevention policy / Compliance policy & 35 & $38.5 \%$ & 91 & u7 & 2 & Information with hyperlinks & 9 & $14.5 \%$ & 62 \\
\hline $\mathrm{p} 8$ & 3 & Remuneration policy & 1 & $1.1 \%$ & 91 & u8 & 2 & Financial information available for at least two years & 41 & $45.1 \%$ & 91 \\
\hline p9 & 3 & Risk-management policy & 16 & $17.6 \%$ & 91 & u9 & 2 & FAQ section (for financial information / transparency section) & 7 & $7.7 \%$ & 91 \\
\hline p10 & 3 & Selection policy for members of the governing body & 1 & $1.1 \%$ & 91 & u10 & 1 & E-mail/online form (transparency/CG information) & 46 & $50.5 \%$ & 91 \\
\hline p11 & 2 & CSR policy/code & 38 & $41.8 \%$ & 91 & u11 & 1 & Phone number/postal address (transparency/CG information) & 70 & $76.9 \%$ & 91 \\
\hline p12 & 2 & CSR annual report & 18 & $19.8 \%$ & 91 & u12 & 2 & Links to information in other websites & 52 & $57.1 \%$ & 91 \\
\hline \multirow[t]{2}{*}{ p13 } & 3 & Mechanisms to report on illegal/unethical conduct & 33 & $36.3 \%$ & 91 & u13 & 2 & Multimedia to support disclosure & 3 & $3.3 \%$ & 91 \\
\hline & & & & & & u14 & 2 & Links to social media channels & 35 & $38.5 \%$ & 91 \\
\hline
\end{tabular}

(*) Note: $1=$ Items whose disclosure is legally required by the Transparency Act (pragmatic legitimacy); $2=$ Disclosure of additional information or good practices in e-disclosure (moral legitimacy); 3 = Disclosure of information about highly valued internal characteristics or procedures (cognitive legitimacy).

ate governance annual report. International initiatives have highlighted the need for corporate accountability to stakeholders by making stakeholder concerns one of the primary principles of corporate governance best practice (Brennan \& Solomon, 2008). Good corporate governance is deemed to provide control while promoting corporate performance so that public value is enhanced and public money is not expropriated or wasted. Thus, SOEs' accountability should also focus on corporate governance elements.

Finally, the usability dimension ("usability", 14 items) assesses the level of stakeholder orientation in e-disclosure practices and covers items addressing the following aspects (Caba et al., 2008; Gandia \& Archidona, 2008; Pina et al., 2010): accessibility to the information, comparability, ease of management of the information, FAQs, and the possibility of establishing a dialog between the SOE and interested stakeholders (interactivity).

\section{Transparency scores and statistical techniques}

Five scores were obtained for each SOE, one per dimension plus a total score, using an equal weighting method. Other methods would require exercising judgement or consultation with key stakeholders to determine the weights to use (da Cruz, Tavares, Marques, Jorge, \& de Sousa, 2016). Three additional scores were calculated by classifying the 60 items into three blocks depending on the different legitimacy status defined by Suchman (1995) (see Table 1). "Pragmatic legitimacy" is the percentage of disclosure of items whose disclosure is legally required by the Transparency Act (21 items). "Moral legitimacy" is the percentage of disclosure of additional information or items that refer to good practices in e-disclosure (28 items). Lastly, "Cognitive legitimacy" is the percentage of disclosure of information about highly valued internal characteristics or procedures (11 items).
To analyze the data obtained through the website content analysis, we first carried out an exploratory analysis to provide a general perspective of the use Spanish SOEs make of their official corporate website for accountability purposes.

Then, in order to identify different accountability patterns among SOEs, cluster, multidimensional scaling (MDS) and Pro-Fit analyses have been carried out ${ }^{6} .42$ of the 60 items were used to carry out these analyses. Items with missing data due to non-applicable information were discarded. Cluster analysis (Ward method) was used to group the SOEs into a small number of homogeneous clusters or groups. The main output of cluster analysis is a dendrogram, which is difficult to interpret when, as in our study, many cases are included (91 SOEs). Therefore, we have complemented the results of cluster analysis with $\mathrm{MDS}^{7}$. The main output of MDS is a graphical representation of the data in two dimensions based on how they use their corporate websites for accountability purposes. Figure 2 combines the results of these two techniques: the map of SOEs obtained through MDS and the groups derived from cluster analysis. Pro-Fit analysis, or property fitting ${ }^{8}$, helps to interpret the dimensions of the MDS map. It is based on regression analysis and its main out-

\footnotetext{
${ }^{6}$ For further details about these techniques, see Serrano, Mar, and Bossi (2003).

${ }^{7}$ MDS maps reduce an ' $n$ '-dimensional space to just two dimensions. The objective of MDS is to describe, geometrically, the relationships existing among different subjects/objects (SOEs) by providing a map that depicts the position of subjects/objects according to the distances or proximities between them. Therefore, SOEs are organized in a map in such a way that the distance between them is an indicator of the degree of relationship.

${ }^{8}$ Pro-Fit analysis is a technique closely related to multivariate regression analysis since it attempts to relate the position of the objects (SOEs) in the MDS configuration to the values of the variables used for the analysis (42 items, in our case). If a variable is related to the position of the objects in the MDS configuration, there is a function which relates the value of the variable to the position of the SOEs on the MDS map (Serrano et al., 2003). Following this reasoning, 42 ordinary least squares regressions were performed in order to interpret the MDS map.
} 
put is a graph that shows the relationships among the variables used for the analysis and the dimensions of the MDS map. Together with Pro-Fit analysis, the average scores of the transparency indexes defined above have been obtained for each group to help identify different accountability patterns among Spanish SOEs.

\section{Results}

\section{Descriptive analysis}

Table 1 shows the average percentages of disclosure of each of the 60 items analyzed. Overall, disclosure levels are not very high. The highest score corresponds to item $\mathrm{u} 4$ (no broken links, 82.4\%) and only 4 additional items have scores above $70 \%$ (f10, f15, u1 and $\mathrm{u} 11$ ). One third of the items analyzed present intermediate average scores ranging from $50 \%$ to $70 \%$. More than $60 \%$ of the items analyzed present average scores below $50 \%$.

In financial and economic information, the items with the highest percentage of disclosure are public procurement information $(70.3 \%)$ and financial statements signed by directors $(76.5 \%)$. We have to note that the number of cases included to calculate the percentage of disclosure for this item is 51 (the number of SOEs disclosing their individual financial statements on their websites). That is, $76.5 \%$ of the SOEs disclosing their financial statements on their websites provided financial statements signed by their directors, but they only represent $42.9 \%$ of the total sample. The percentages of disclosure of financial statements were $56 \%$ for the balance sheet and income statement and 52.7\% for the notes. $59 \%$ of the SOEs subject to audit publish their audit reports. However, only $35.2 \%$ of the SOEs publish some kind of performance or quality indicators. Therefore, a first finding is that not all SOEs upload the economic and financial information they are obliged to publish under the Transparency Act. It can also be appreciated that the disclosure of budgetary information (operating budget -forecast income statementand capital budget -forecast statement of cash flows-) is very rare, with percentages of disclosure around $10 \%$. The item in this dimension with the lowest percentage of disclosure is the average period of payment to suppliers $(2.2 \%)$.

The percentages of disclosure in objectives, policies and strategies are much lower. Only one item in this dimension scores above $50 \%$ (organization chart, $65.9 \%$, the only item in this dimension that SOEs are explicitly required to publish). Around $40 \%$ of the companies analyzed disclose some kind of code of conduct or good governance or a fraud prevention or compliance policy, but the scores for the rest of the items are extremely low. Only $31.9 \%$ of the companies disclose their objectives and only $19.8 \%$ publish a CSR report. The items in this dimension with the lowest levels of disclosure are annual objectives with defined indicators, remuneration policy and selection policy for members of the governing body, which are disclosed by just one or two of the SOEs analyzed.

The percentages of disclosure in corporate governance information are also very low. Only three items in this dimension score above 50\%: SOEs ownership structure (61.5\%), list of members of the governing body (59.3\%) and top management composition (67\%). Strikingly, a number of items whose disclosure is compulsory obtain very low scores: CVs of the members of the governing body and top managers $(22.5 \%$ and $41.2 \%)$ and remunerations of the members of the governing body and top managers (with average scores below $20 \%$ ). Only $13.2 \%$ of the companies publish a corpor- ate governance annual report. For SOEs with a $\mathrm{BoD}(\mathrm{N}=81)$, information about the operation of the board, status of directors and committees within the board is very rare. Indeed, none of the companies informed about the number of meetings of the BoD.

As regards usability, as commented above, three out of the five items with the highest scores in all the sample belong to the usability dimension: no broken links (82.4\%), link to the transparency section in the homepage $(80.2 \%)$ and phone number or postal address to ask for transparencyrelated information (76.9\%). However, items that are critical to enhance the usability of the financial information disclosed and stakeholder orientation in e-disclosure practices have very low scores: e-mail alerts/RSS (16.5\%), ease of management of the information (27.4\%), information with hyperlinks (14.5\%), FAQ section (7.7\%) and the use of multimedia to support disclosure (3.3\%). Furthermore, only $45.1 \%$ of the companies publish financial information for at least two years, hampering comparability. Although most SOEs place a direct link to the transparency section in their homepage, the contents published there are rather limited and only $57.1 \%$ of the companies put links to other government websites containing financial and economic information. Therefore, it seems that the most common e-disclosure practices are the dissemination of partial information. Furthermore, many companies are not making it easy for interested parties to request information. The Transparency Act (art. 17) requires public sector organizations to establish the necessary channels for this type of requests, giving preference to electronic communications. However, not all the companies disclose contact details in order to make this type of request and offline communication seems to be preferred; $76.9 \%$ provide a phone number or postal address, whereas only $50.5 \%$ provide an e-mail or online form.

Table 2 presents the descriptive statistics of the different transparency scores calculated. As can be seen, the average scores are quite low, being below $50 \%$ for all the indexes calculated. Financial and usability dimensions present the highest average scores (just above 40\%), whereas the disclosure of information about objectives, policies and corporate governance is much less common (mean scores around 25\%). The total average score is just 34\%, showing that e-disclosure practices in Spanish SOEs have much room for improvement. As regards the legitimacy status of the items analyzed, results show that the average percentage of disclosure of the items required by the Transparency Act (46.4\%) is higher than for the other items. The average percentage of disclosure of additional information or items that refer to good practices in e-disclosure is just $32.6 \%$, whereas the disclosure of information about highly valued internal characteristics or procedures is very limited (16.9\%). In any case, the figures for the minimum, maximum and standard deviation show that there are important differences among the SOEs analyzed. The maximum scores in all dimensions correspond to AENA ${ }^{9}$, the only company analyzed which is listed on a stock market. Another 4 SOEs have a total score higher than $60 \%$. As can be seen in Table 2 , the median value for the financial dimension $(61.5 \%)$ is significantly higher than the mean value $(42.7 \%)$. This means that half of the companies analyzed present financial scores higher than $61.5 \%$. However, many companies analyzed have very low scores in this dimension, driving the average score down. Specifically, 42 companies obtain a financial score below $40 \%$ and 18 companies have a financial

\footnotetext{
${ }^{9}$ The individual scores of SOEs per dimension have not been included in the paper because of space requirements, but they are available from the authors upon request.
} 
Table 2

Scores by dimension, type of items and total scores.

\begin{tabular}{lccccc}
\hline & Mean & Median & Min & Max & Stand. Dev. \\
\hline FINANCIAL & $42.7 \%$ & $61.5 \%$ & $0.0 \%$ & $92.3 \%$ & 0.3259 \\
POLICIES & $26.2 \%$ & $23.1 \%$ & $0.0 \%$ & $84.6 \%$ & 0.2167 \\
CORPORATE & $25.6 \%$ & $25.0 \%$ & $0.0 \%$ & $87.5 \%$ & 0.1823 \\
USABILITY & $44.0 \%$ & $42.9 \%$ & $0.0 \%$ & $85.7 \%$ & 0.2019 \\
Pragmatic legitimacy & $46.4 \%$ & $52.6 \%$ & $0.0 \%$ & $95.2 \%$ & 0.2713 \\
Moral legitimacy & $32.6 \%$ & $32.0 \%$ & $0.0 \%$ & $71.4 \%$ & 0.1617 \\
Cognitive legitimacy & $16.9 \%$ & $9.1 \%$ & $0.0 \%$ & $81.8 \%$ & 0.1791 \\
\hline TOTAL & $\mathbf{3 4 . 1 \%}$ & $\mathbf{3 6 . 4} \%$ & $\mathbf{0 . 0} \%$ & $\mathbf{8 1 . 7} \%$ & $\mathbf{0 . 1 8 4 5}$ \\
\hline
\end{tabular}

score of $0 \%$. We also want to note that, except for AENA, scores in "Corporate" and "Cognitive legitimacy" dimensions are rather low in all the companies. The maximum score in corporate information $(87.5 \%)$ is followed by a score of 59.4\%. Only 9 SOEs, including AENA, have scores of at least $50 \%$ in this dimension. For information about highly valued internal characteristics or procedures (Cognitive legitimacy), the maximum score $(81.8 \%)$ is followed by a score of $54.5 \%$, and only 3 companies have scores higher than $50 \%$ in this dimension.

\section{Multidimensional scaling and cluster analysis}

Figure 2 shows the distribution map of SOEs, applying the MDS $^{10}$ technique to the 42 items of information applicable to all the companies (i.e., $\mathrm{N}=91$ in Table 1). The four groups have been drawn up according to their statistical proximity, as measured through cluster analysis.

The two dimensions of Figure 2 have been interpreted based on Pro-Fit analysis. As can be seen in Figure 3, all the Pro-Fit vectors point towards the positive side of dimension 1. Therefore, dimension 1 summarizes all the items analyzed and is related to higher quality e-disclosure practices. The ordering of SOEs from right to left is related to higher total scores per company (the Pearson correlation coefficient between the value of dimension 1 and the total score is 0.98). Dimension 2 is made up of two groups of variables: those pointing to the upper half of dimension 2 and those pointing to the lower half of dimension 2 . The variables associated with dimension 2 in the upper half are mainly related to the disclosure of financial information: balance sheet (f3), income statement (f4), statement of changes in equity (f6), notes (f7), financial information available for several years (u8) and capital budget (f2). In the lower half, dimension 2 is mainly associated with the following variables: performance/quality indicators (f17), code of conduct (p6), CSR policy/code (p11), mechanisms to report illegal/unethical conduct (p13), corporate governance annual report (c1), list of members of the governing body (c4), top management composition (c8), website map (u2), internal search engine (u3) and phone number or postal address to ask for transparency-related information (u11). Therefore, SOEs located in the upper half of dimension 2 show a higher weight for financial information, whereas those located in the lower half show a higher weight for policy and corporate information together with features that increase usability and stakeholder orientation. This reveals two conflicting accountability approaches in the SOEs analyzed: those that take a narrow approach to accountability, focusing on financial in-

\footnotetext{
${ }^{10}$ In the MDS analysis, the value of Kruskal stress in six dimensions was 0.115 , which could be described as "fair" (Kruskal, 1964). To visualize the map, it is necessary to work with projections of the map onto pairs of dimensions. Figure 2 shows the projection of the map onto dimension 1 and dimension 2 .
}

Table 3

Average scores in the four groups of SOEs identified.

\begin{tabular}{lccccc}
\hline & \multicolumn{5}{c}{ Group } \\
& $\mathbf{1}$ & $\mathbf{2}$ & $\mathbf{3}$ & $\mathbf{4}$ & Total \\
\hline FINANCIAL & $57.2 \%$ & $71.0 \%$ & $8.1 \%$ & $3.3 \%$ & $42.7 \%$ \\
POLICIES & $52.1 \%$ & $21.6 \%$ & $18.0 \%$ & $2.4 \%$ & $26.2 \%$ \\
CORPORATE & $41.2 \%$ & $26.2 \%$ & $22.4 \%$ & $2.7 \%$ & $25.6 \%$ \\
USABILITY & $60.2 \%$ & $45.7 \%$ & $40.5 \%$ & $18.5 \%$ & $44.0 \%$ \\
Pragmatic legitimacy & $66.9 \%$ & $62.1 \%$ & $27.6 \%$ & $3.7 \%$ & $46.4 \%$ \\
Moral legitimacy & $46.7 \%$ & $37.0 \%$ & $23.4 \%$ & $11.8 \%$ & $32.6 \%$ \\
Cognitive legitimacy & $39.5 \%$ & $11.1 \%$ & $9.1 \%$ & $0.0 \%$ & $16.9 \%$ \\
\hline TOTAL & $52.2 \%$ & $40.3 \%$ & $22.0 \%$ & $6.6 \%$ & $34.1 \%$ \\
\hline
\end{tabular}

formation (agency theory point of view) and those that understand accountability in a broader way. It should be noted that the financial information associated with the upper half of dimension 2 is available from other sources (Transparency portal), whereas this is not the case for performance indicators and the information in the policies and corporate dimensions. Therefore, companies focusing on the disclosure of the items associated with the upper half of dimension 2 are not providing any added value, except for the convenience of making this information available on the corporate website. In any case, overall, we cannot conclude that companies located in the lower half of Figure 2 perform better than those located in the upper half. For this type of overall comparisons in e-disclosure practices, the position in dimension 1 has to be considered.

Group 1 includes 26 SOEs. Most of them are big companies that prepare individual annual accounts in the standard format and consolidated financial statements. Indeed, 7 of the 10 parent companies in the sample are included in this group. However, 3 small companies using the abbreviated format to elaborate their individual annual accounts are also included in this group. All the companies in this group have a BoD. This group is on the right-hand side of dimension 1 and has the highest scores in all the dimensions studied except for the "financial score" (see Table 3). Its mean total score is $52.2 \%$. Most of the SOEs in this group are in the lower half of dimension 2, showing that these companies are those giving more importance to policy and corporate information together with features that increase usability and stakeholder orientation.

Group 2 includes 31 SOEs. As in Group 1, most of them are big companies that prepare individual annual accounts in the standard format and all of them have a BoD. Two parent companies preparing consolidated financial statements are included, but the number of small companies using the abbreviated format to elaborate their annual accounts is higher (9 SOEs, representing almost 30\% of the companies included in this group). Most of the SOEs in this group are also on the right-hand side of dimension 1 , but most of them are in the upper half of dimension 2. Its mean total score is $40.3 \%$, showing a lower degree of e-disclosure. Its position in the upper half of dimension 2 evidences a greater emphasis on the disclosure of financial information. Indeed, Group 2 obtains the highest average score in this dimension (71\%). All SOEs in this group disclose their balance sheet, income statement, audit report, and financial statements signed by directors.

Group 3 includes 18 SOEs. Half of them present abbreviated annual accounts and only one parent company required to prepare consolidated annual accounts is included. Four of the companies in this group do not have a BoD. This group is on the left of dimension 1, which shows poor e-disclosure practices (with an average total score of $22 \%$ ). As can be 


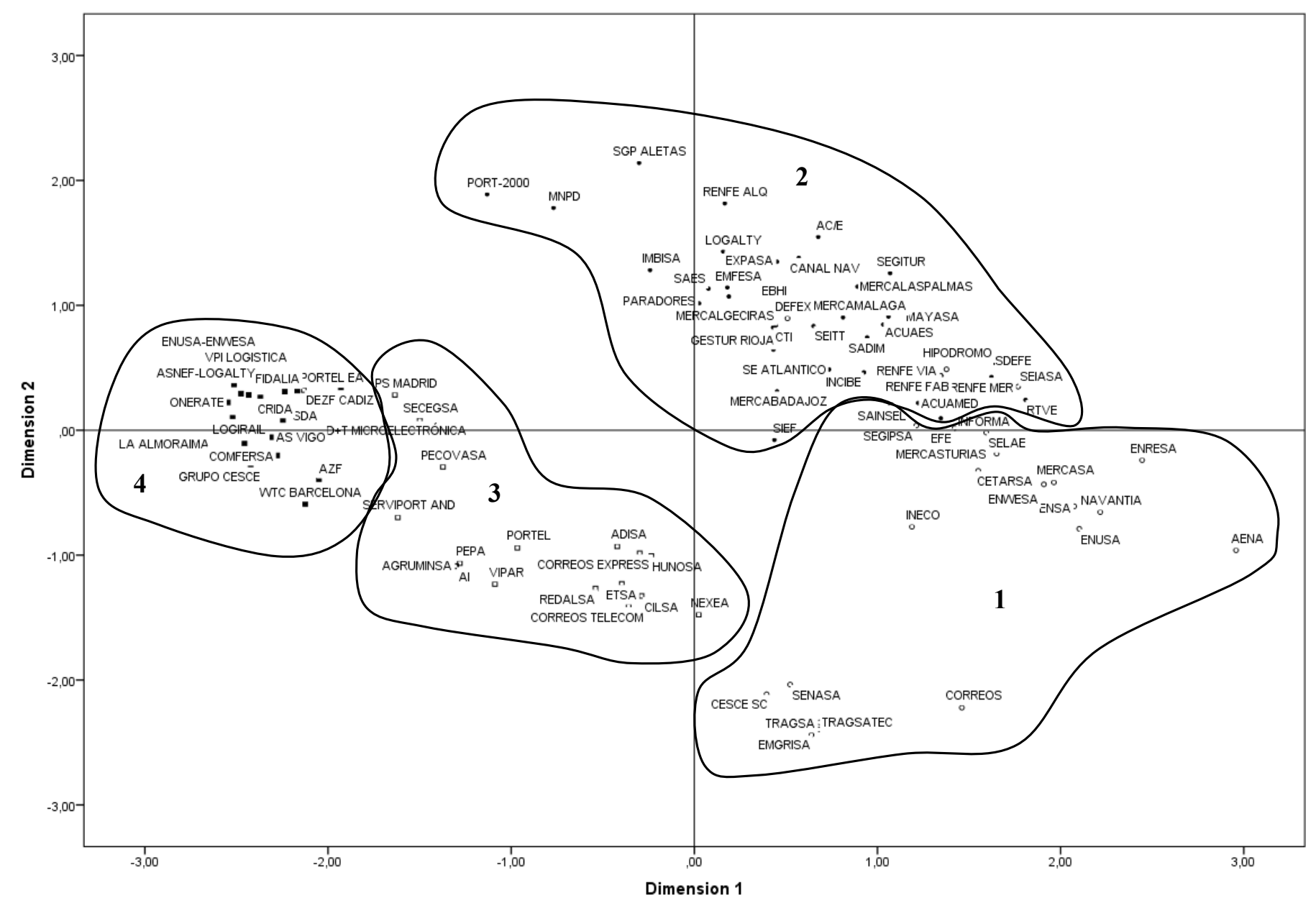

seen in Table 3, they have much lower scores than Group 2 in financial information $(8.1 \%$, with all the financial items in this group but public procurement and performance/quality indicators having an average score of $0 \%$ ), whereas the average scores in policies, corporate and usability are closer to the previous group.

Group 4, which includes 16 SOEs and is on the extreme left of dimension 1 , is made up of enterprises that make hardly any use of their corporate website for the dissemination of financial, corporate or policy-related information. As can be seen in Table 3, their very low total scores come from the usability dimension. Most of the companies in this group (11 companies) are small companies preparing their annual accounts using the abbreviated format and none of the SOEs included is required to prepare consolidated annual accounts. Most of the companies in the sample which do not have a BoD (6 out of 10) are included in this group.

\section{Discussion}

The Spanish context reveals some attempts at the legal level to improve downward accountability. However, SOEs' e-disclosure practices are still in their infancy. Results show that downward transparency is not a priority for most Spanish SOEs. Financial and economic information and the items related to usability obtain the highest levels of disclosure, with average scores of around 40-45\%. The results on the disclosure of information about objectives, policies and strategies, or related to corporate governance issues are worse, with average scores of around 25\%. As shown by previous studies at the local level (Pina et al., 2010; Pina et al., 2009), only information already available and easily obtained, such as most of the items in the financial dimension, is disclosed, and even this dimension shows, on average, low levels of disclosure.

Stakeholder orientation does not seem to be a concern for Spanish SOEs: financial accountability is their main focus and most are silent about their policies, objectives and corporate governance structures. These findings are consistent with previous research (Alexius \& Cisneros, 2015; Daiser et al., 2017; Greiling et al., 2015), highlighting the prioritization of financial values and an economic logic despite formal aspirations to balance the values at stake (including non-financial values, such as sustainability, environmental and social values). This contrasts with the traditional type of legal system in Spain (code law) which, according to Ball et al. (2000), characterizes Spain as having a "stakeholder governance model". However, our results suggest that most Spanish SOEs follow a shareholder governance model.

Agency and stakeholder theories confirm the need for legislation and enforcement (urgency) to fulfill downward accountability. Spanish SOEs have not yet adopted a proactive approach to transparency by supplying corporate information to citizens through their websites. Legitimacy and stakeholder theories argue that motivation for voluntary disclosure takes place when there is higher visibility, urgency and pressure from stakeholders. Other public sector entities, such as big local governments, probably feel more pressure to be 
Figure 3

Pro-Fit vectors

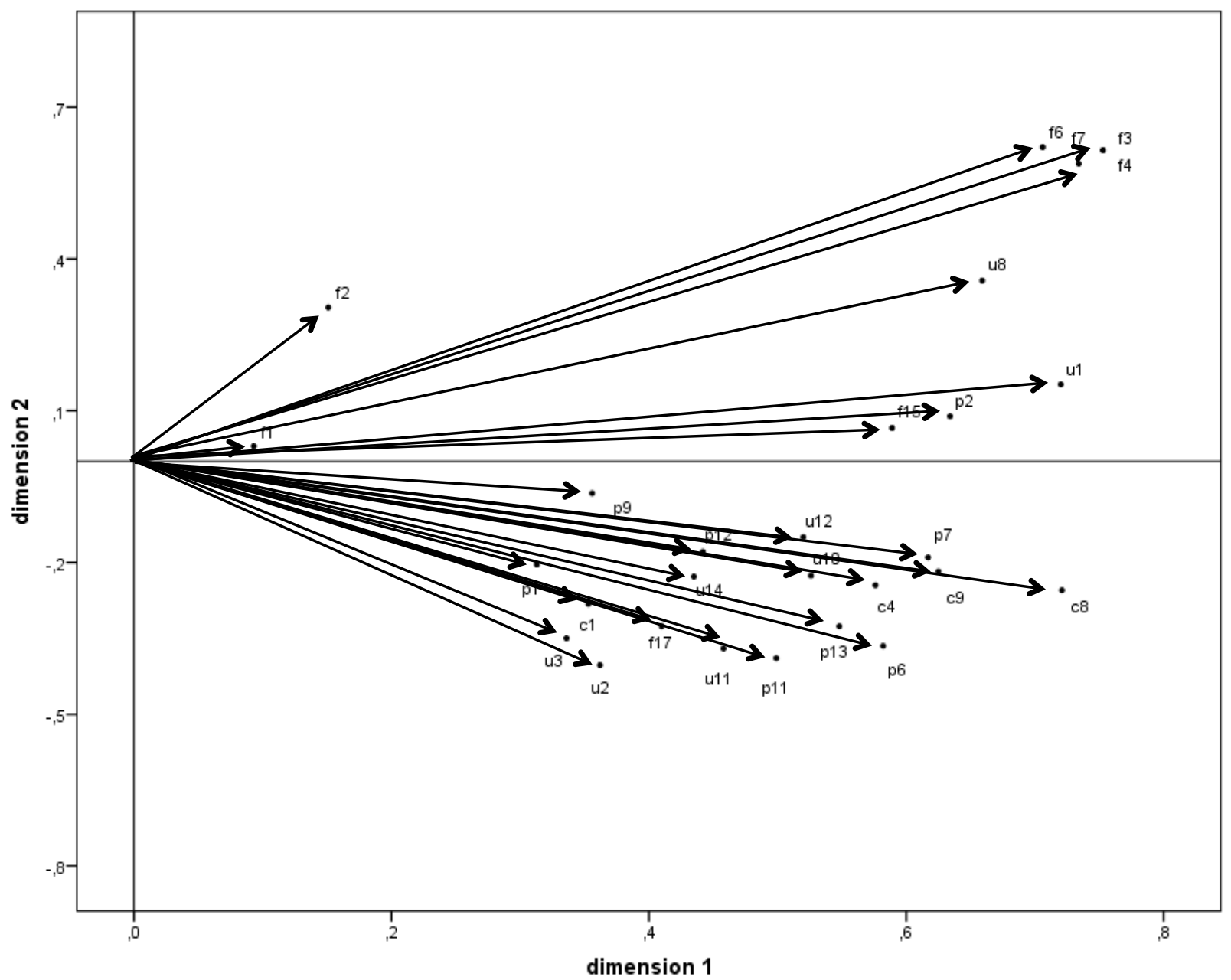

accountable to the public as a whole, particularly because they have been under close scrutiny from think tanks, academia and non-government organizations. For example, big local governments have been subject to periodic transparency assessments by Transparency International-Spain (Araujo \& Tejedo-Romero, 2018). This type of assessments had not been carried out for Spanish SOEs when data collection for this study took place ${ }^{11}$. Elections may also be a major source of accountability pressures. As anticipated by legitimacy theory, larger SOEs have, in general terms, higher levels of edisclosure, very probably due to their higher visibility. In fact, AENA (airports), the only listed company in the sample, and other companies with high levels of visibility such as RENFE (trains), CORREOS (post), EFE (news services) and SELAE (lottery) are included in the group with the highest levels of disclosure. However, in the context under study, urgency and pressure from stakeholders do not seem to be perceived by the majority of the SOEs.

The analysis of the items depending on their legitimacy status (legal requirements, best practices or professionalization) shows that the highest levels of disclosure are for

\footnotetext{
${ }^{11}$ Transparency International Spain (2018) has recently released its first transparency assessment for the 45 biggest SOEs in Spain, also obtaining very low results (45.3\%, on average), even though the SOEs were informed about the preliminary scores obtained (initial average of $28.6 \%$ ) and given the possibility to update their websites or indicate where in the website the information was published. As can be appreciated, this two-step procedure resulted in a remarkable improvement in the transparency scores, but much room for improvement still exists.
}

items legally required by the Transparency Act, with average scores of $46.4 \%$. The average score for items related to best practices and professionalization are lower, $32.6 \%$ and $16.9 \%$, respectively. In any case, the low average scores even for legally required items evidences that enforcement of transparency-related legislation is an issue in the Spanish context. The government is not controlling downward accountability to the same extent as upward accountability, which is why Spanish SOEs consider downward transparency as of low urgency. The budgetary information of these entities is part of the State budget. This information is elaborated and communicated to the corresponding Ministry (who must approve it), but hardly any SOEs provide it through their websites. This contrasts with other public institutions that disclose budgetary information to a greater extent than financial information, indicating that accountability in hybrid organizations is perceived differently than in fully public entities. In this sense, SOEs seem to have a corporate accountability approach closer to the private than to the public sector.

Spanish SOEs do not perceive citizens as key stakeholders or, at least, do not consider the need to provide greater disclosure to the community with the same urgency as international organizations, such as the OECD and the World Bank. This is consistent with the traditional public administration style in Continental and Southern European countries, which has a greater focus on upward than on downward accountability (Bastida \& Benito, 2007; Pina et al., 2010). The stakeholder orientation of Spanish SOEs follows the common pattern in Southern European countries in which the citizen is 
considered to be a recipient of services rather than an active participant. Thus, most SOEs are still anchored in a narrow accountability style that only considers shareholders as the key stakeholders. As regards citizens and downward transparency, minimally complying with legal requirements, at best, is considered to be enough. Therefore, there is a hybrid accountability pattern in Spanish SOEs, with a corporate accountability approach closer to the private than to the public sector, but also showing some of the distinctive features of the traditional public sector administrative culture in Southern European countries.

The Spanish SOE sector is characterized by weak compliance procedures, with low levels of disclosure even in legally required information. Previous research analyzing local governments has highlighted that non-conformance to transparency regulations is an important issue in the Spanish public sector (Martí, Royo, \& Acerete, 2012). The low scores in the cognitive legitimacy (professionalization) index also show that, in general, Spanish SOEs have weak internal controls and processes. Recent corruption scandals in Spanish SOEs and the increased attention to public sector transparency and accountability should have resulted in more disclosure because organizations are expected to associate additional disclosures with "more accountability", in line with the socially constructed system of norms, values and beliefs. However, our results indicate that this has not been the case in the context analyzed. As said before, transparency-related pressures are perceived to a greater extent in other layers of government.

Three different patterns of accountability can be defined for Spanish SOEs corresponding to the behavior of the 4 groups obtained with cluster analysis. Group 1, the good, includes the SOEs with a more balanced approach to transparency, with medium-high scores in all the indexes and using their corporate websites as an integrated platform to improve information dissemination and satisfy stakeholder needs. However, even in this group, there is room for improvement. One entity stands out from the rest: AENA, the pretty one in terms of e-disclosure. It is the only listed SOE and, thus, is subject to both public accountability and "real" shareholder accountability. Its high level of e-disclosure is most probably due to greater enforcement of disclosure requirements as a listed company because it is subject to the monitoring of an independent watchdog, the CNMV sheriff. Groups 3 and 4, the bad, hardly disclose any type of information. SOEs in Group 2 are the ugly. They are strongly focused on the disclosure of mandatory information, particularly the financial information legally required by the Transparency Act. However, they fail to present policy and corporate information.

Results indicate that, in general terms, size and visibility are related to higher levels of e-disclosure, but some exceptions suggest that managerial will is an important driver. Overall, our findings suggest that accountability, like legitimation, is not homogeneous, and that the different facets of accountability are somewhat conflictive. Spanish SOEs are a long way from fulfilling the OECD (2005b, 2015b) recommendation that they should be as transparent as listed companies. Furthermore, results also highlight the existence of a weak institutional environment in Spain as regards public sector transparency and e-disclosure. As Suchman (1995) indicates, in these settings, organizations very often adhere to the most superficial forms of legitimation (pragmatic legitimacy), minimally complying to legal requirements. However, as this author indicates, there are "typical" legitimation progressions.
As in all web content analyses, this study is just a snapshot of SOEs' e-disclosure practices at a specific moment in time. As the Internet is evolving continuously, the results of this study will not be valid forever, and future research should update the findings obtained here. This paper has only analyzed the presence of certain items/information on the official websites, but not the quality of the information disclosed. Further longitudinal studies would be useful to assess whether SOEs accountability practices are evolving towards the adoption of best practices in e-disclosure and conformance to established models and standards, as the typical legitimation progressions proposed by Suchman (1995) suggest. Future research should also analyze the drivers of higher levels of e-disclosure in greater depth by proposing and testing a theoretical model to explain the differences in SOEs' e-disclosure levels. Future studies in other countries and public administration styles would also be useful to test whether the accountability styles found for Spanish SOEs can be extrapolated to other settings.

\section{Conclusions}

This paper aims to identify the e-disclosure patterns that SOEs follow to render accountability to citizens. Overall, Spanish SOEs do not consider corporate websites as a key medium to communicate with their stakeholders and do not feel any real urgency to comply with transparency-related legal requirements or legitimate pressures from their stakeholders to keep them informed. Financial accountability is the main focus and most SOEs are silent about their policies, objectives and corporate governance structures. The majority of them are still anchored in a narrow accountability style that only considers shareholders as the key stakeholders and are a long way from fulfilling the OECD recommendation that they should be as transparent as listed companies. Based on their e-disclosure behaviors, three different patterns of accountability have been found in Spanish SOEs: the good (balanced approach to transparency, using their corporate websites as an integrated platform to improve information dissemination and satisfy stakeholder needs), the bad (they hardly disclose any type of information) and the ugly (strongly focused on the disclosure of mandatory information, particularly the financial information legally required by the Transparency Act). AENA stands out among the good as the pretty.

Spanish SOEs still have to make important efforts to promote downward accountability to citizens. The practical implications of this research are that SOEs' managers have to increase downward accountability and that professionals involved in the external overseeing of SOEs must strive to enforce transparency requirements. As enforcement of transparency-related legislation is scarce in Spain, measures should be adopted to improve compliance and foster a truly proactive approach in promoting downward accountability to citizens. Based on our findings, the following recommendations to improve e-disclosure practices among SOEs are suggested. First, the enforcement and adoption of additional e-disclosure requirements, under the supervision of a sheriff, an independent monitoring body, is needed. This has proven to be effective for listed companies and other public sector entities. In the UK, for example, the Foundations Trusts of the English National Health Service are under the supervision of an independent watchdog, Monitor, with its own Code of Governance, which enhances public accountability (see e.g. Ellwood and Garcia-Lacalle, 2016). Other measures include: the publication of guidance manuals; training seminars; the adoption of mechanisms to periodically meas- 
ure, assess and report the implementation of disclosure requirements by SOEs; and performance awards to individual SOEs for high quality disclosure practices (OECD, 2015b). International comparisons may shed light on which measures are more effective to promote downward accountability to citizens.

\section{Acknowledgments}

This study has been carried out with the financial support of the Spanish National Research and Development Plan (project ECO2015-66240-P MINECO/FEDER) and the Regional Government of Aragón/FEDER (project S56-17R).

\section{Conflicts of interest}

The authors have no conflicts of interest to declare.

\section{References}

Alexius, S., \& Cisneros, J. (2015). Mission(s) impossible? Configuring values in the governance of state-owned enterprises. International Journal of Public Sector Management, 28(4/5), 286-306.

Allini, A., Manes Rossi, F., \& Hussainey, K. (2016). The board's role in risk disclosure: an exploratory study of Italian listed state-owned enterprises. Public Money \& Management, 36(2), 113-120.

Araujo, J. F. F. E., \& Tejedo-Romero, F. (2018). Does Gender Equality Affect Municipal Transparency: The Case of Spain. Public Performance \& Management Review, 41(1), 69-99.

Bachiller, P. (2009). Effect of ownership on efficiency in Spanish companies. Management Decision, 47(2), 289-307.

Ball, R., Kothari, S. P., \& Robin, A. (2000). The effect of international institutional factors on properties of accounting earnings. Journal of Accounting and Economics, 29(1), 1-51.

Bastida, F., \& Benito, B. (2007). Central government budget practices and transparency: An international comparison. Public Administration, 85(3), 667-716.

Behn, R. D. (2001). Rethinking Democratic Accountability. Washington, DC: Brookings Institution Press.

Bonsón, E., \& Bednárová, M. (2015). CSR reporting practices of Eurozone companies. Revista de Contabilidad, 18(2), 182-193.

Bonsón, E., \& Flores-Muñoz, F. (2014). A microsimulation approach to corporate disclosure policies. Online Information Review, 38(7), 861-880.

Bovens, M., Schillemans, T., \& Hart, P. T. (2008). Does public accountability work? An assessment tool. Public Administration, 86(1), 225-242.

Brennan, N. M., \& Solomon, J. (2008). Corporate governance, accountability and mechanisms of accountability: an overview. Accounting, Auditing \& Accountability Journal, 21(7), 885-906.

Broadbent, J., \& Laughlin, R. C. (2003). Control and legitimation in government accountability processes: the private finance initiative in the UK. Critical Perspectives on Accounting, 14(1/2), 1-22.

Bruton, G. D., Peng, M. W., Ahlstrom, D., Stan, C., \& Xu, K. (2015). State-owned Enterprises Around the World as Hybrid Organizations. Academy of Management Perspectives, 29(1), 92-114.

Caba, C., Rodriguez, M. P., \& López, Antonio M. (2008). e-Government process and incentives for online public fin- ancial information. Online Information Review, 32(3), 379400.

Cabeza, L., \& Gómez, S. (2007). The Spanish privatisation process: Implications on the performance of divested firms. International Review of Financial Analysis, 16(4), 390-409.

Cameron, W. (2004). Public accountability: Effectiveness, equity, ethics. Australian Journal of Public Administration, 63, 59-67.

Célérier, L., \& Cuenca-Botey, L. E. (2015). Participatory budgeting at a community level in Porto Alegre: a Bourdieusian interpretation. Accounting, Auditing \& Accountability Journal, 28(5), 739-772.

Chan, Y. C. L. (2003). Government accounting: An assessment of theory, purposes and standards. Public Money \& Management, 23(1), 13-20.

Chiwamit, P., Modell, S., \& Scapens, R. W. (2017). Regulation and adaptation of management accounting innovations: The case of economic value added in Thai state-owned enterprises. Management Accounting Research, 37, 30-48.

Cohen, S., Mamakou, X. J., \& Karatzimas, S. (2017). ITenhanced popular reports: Analyzing citizen preferences. Government Information Quarterly, 34(2), 283-295.

Collier, P. M. (2008). Stakeholder accountability: A field study of the implementation of a governance improvement plan. Accounting, Auditing \& Accountability Journal, 21(7), 933-954.

Cormier, D., Magnan, M., \& Van Velthoven, B. (2005). Environmental disclosure quality in large German companies: Economic incentives, public pressures or institutional conditions? European Accounting Review, 14(1), 3-39.

Cucciniello, M., Bellè, N., Nasi, G., \& Valotti, G. (2015). Assessing Public Preferences and the Level of Transparency in Government Using an Exploratory Approach. Social Science Computer Review, 33(5), 571-586.

Cucciniello, M., Porumbescu, G. A., \& Grimmelikhuijsen, S. (2017). 25 Years of Transparency Research: Evidence and Future Directions. Public Administration Review, 77(1), 3244.

da Cruz, N. F., Tavares, A. F., Marques, R. C., Jorge, S., \& de Sousa, L. (2016). Measuring Local Government Transparency. Public Management Review, 18(6), 866-893.

Daiser, P., Ysa, T., \& Schmitt, D. (2017). Corporate governance of state-owned enterprises: a systematic analysis of empirical literature. International Journal of Public Sector Management, 30(5), 447-466.

Deegan, C. (2002). The legitimising effect of social and environmental disclosures - a theoretical foundation. Accounting, Auditing \& Accountability Journal, 15(3), 282-311.

Ebrahim, A., Battilana, J., \& Mair, J. (2014). The governance of social enterprises: Mission drift and accountability challenges in hybrid organizations. Research in Organizational Behavior, 34, 81-100.

Ellwood, S. \& Garcia-Lacalle, J. (2016). Examining Audit Committees in the Corporate Governance of Public Bodies. Public Management Review, 18(8), 1138-1162.

European Commission. (2016). State-Owned Enterprises in the EU: Lessons Learnt and Ways Forward in a Post-Crisis Context. https://ec.europa.eu/info/publications/ (accessed 30 October 2017).

Florio, M., Ferraris, M., \& Vandome, D. (2018). StateOwned Enterprises: Rationales for Mergers and Acquisitions. Centre International de Recherches et d'Information sur l'Economie Publique, Sociale et Coopérative (CIRIEC) Working Paper No. 2018/01. http://www.ciriec.uliege.be/ wp-content/uploads/2018/04/WP2018-01.pdf (accessed 5 
October 2018).

Freeman, E. (1984). Strategic Management: A Stakeholder Approach. Boston: Pitman.

Gallego-Álvarez, I., \& Quina-Custodio, I. A. (2016). Disclosure of corporate social responsibility information and explanatory factors. Online Information Review, 40(2), 218238.

Gandia, J. L., \& Archidona, M. C. (2008). Determinants of web site information by Spanish city councils. Online Information Review, 32(1), 35-57.

Government of Spain. (2013). Ley 19/2013, de 9 de diciembre, de transparencia, acceso a la información pública y buen gobierno. https://www.boe.es/buscar/doc.php?id= BOE-A-2013-12887 (accessed 20 September 2018).

Greiling, D., Traxler, A. A., \& Stötzer, S. (2015). Sustainability reporting in the Austrian, German and Swiss public sector. International Journal of Public Sector Management, 28(4/5), 404-428.

Grossi, G., PapenfuSS, U., \& Tremblay, M.-S. (2015). Corporate governance and accountability of state-owned enterprises: Relevance for science and society and interdisciplinary research perspectives. International Journal of Public Sector Management, 28(4/5), 274-285.

Grossi, G., \& Thomasson, A. (2015). Bridging the accountability gap in hybrid organizations: the case of Copenhagen Malmö Port. International Review of Administrative Sciences, 81(3), 604-620.

Heald, D. (2006). Varieties of Transparency. In C. Hood \& D. Heald (Eds.), Transparency: The Key to Better Governance? London: The Bristish Academy.

Hodges, R., Wright, M., \& Keasey, K. (1996). Corporate governance in the public services: Concepts and issues. Public Money \& Management, 16(2), 7-13.

Hood, C., \& Heald, D. (2006). Transparency: The Key to Better Governance? London: The Bristish Academy.

ICAEW. (2014). Trust in public finances. A survey of citizens in 10 European countries. http://www.pwc.com/gx/ en/services/european-union/eu-public-finance-survey.html: Accessed 15th March 2016.

IIRC. (2016). Integrated thinking and reporting. Focusing on value creation in the public sector. http:// integratedreporting.org (accessed 3 October 2018). International Integrated Reporting Council (IIRC) and the Chartered Institute of Public Finance \& Accountancy (CIFPA).

Kopits, G., \& Kraig, D. (1998). Transparency in Government Operations. IMF Occasional Papers 158, Washington DC: International Monetary Fund.

Kruskal, J. B. (1964). Multidimensional scaling by optimizing goodness of fit to a nonmetric hypothesis. Psychometrika, 29(1), 1-27.

Letza, S. R., Smallman, C., \& Sun, X. (2004). Reframing privatisation: Deconstructing the myth of efficiency. Policy Sciences, 37(2), 159-183.

Luke, B. (2010). Examining Accountability Dimensions in State-Owned Enterprises. Financial Accountability \& Management, 26(2), 134-162.

Mack, J., \& Ryan, C. (2006). Reflections on the theoretical underpinnings of the generalpurpose financial reports of Australian government departments. Accounting, Auditing \& Accountability Journal, 19(4), 592-612.

Martí, C., Royo, S., \& Acerete, B. (2012). The Effect of New Legislation on the Disclosure of Performance Indicators: The Case of Spanish Local Governments. International Journal of Public Administration, 35(13), 873-885.

Meyer, J. W., \& Rowan, B. (1977). Institutionalized Organizations: Formal Structure as Myth and Ceremony. The
American Journal of Sociology, 83(2), 340-363.

Mitchell, R. K., Agle, B. R., \& Wood, D. J. (1997). Toward a Theory of Stakeholder Identification and Salience: Defining the Principle of Who and What Really Counts. The Academy of Management Review, 22(4), 853-886.

Mulgan, R. (2000). 'Accountability': An Ever-Expanding Concept? Public Administration, 78(3), 555-573.

Ntim, C. G., Soobaroyen, T., \& Broad, M. J. (2017). Governance structures, voluntary disclosures and public accountability: The case of UK higher education institutions. Accounting, Auditing \& Accountability Journal, 30(1), 65-118.

OECD. (2005a). Corporate Governance of State-Owned Enterprises. A Survey of OECD Countries. Paris: OECD.

OECD. (2005b). OECD Guidelines on Corporate Governance of State-Owned Enterprises. Paris: OECD.

OECD. (2015a). G20/OECD Principles of Corporate Governance. Paris: OECD Publishing.

OECD. (2015b). OECD Guidelines on Corporate Governance of State-Owned Enterprises, 2015 Edition. Paris: OECD Publishing.

OECD. (2016). State-Owned Enterprises as Global Competitors. A Challenge or an Opportunity? Paris: OECD Publishing.

OECD. (2017). The Size and Sectoral Distribution of StateOwned Enterprises. Paris: OECD Publishing.

Oliver, R. W. (2004). What is transparency? New York: McGraw-Hill.

Pérez, A., López, C., \& García-De los Salmones, M. d. M. (2017). An empirical exploration of the link between reporting to stakeholders and corporate social responsibility reputation in the Spanish context. Accounting, Auditing \& Accountability Journal, 30(3), 668-698.

Peters, B. G. (2007). Performance-Based Accountability. In A. Shah (Ed.), Performance accountability and Combating Corruption (pp. 15-32). Washington, DC: The World Bank.

Pina, V., Torres, L., \& Royo, S. (2010). Is E-Government Promoting Convergence Towards More Accountable Local Governments? International Public Management Journal, 13(4), 350-380.

Pina, V., Torres, L., \& Yetano, A. (2009). Accrual accounting in EU local governments: One method, several approaches. European Accounting Review, 18(4), 765-807.

Royo, S., Yetano, A., \& Acerete, B. (2014). E-Participation and Environmental Protection: Are Local Governments Really Committed? Public Administration Review, 74(1), 8798.

Rygh, A. (2018). Welfare effects of state-owned multinational enterprises: A view from agency and incomplete contracts theory. International Journal of Public Sector Management, 31(2), 207-220.

Serrano, C., Mar, C., \& Bossi, A. (2003). The measurement of intangible assets in public sector using scaling techniques. Journal of Intellectual Capital, 4(2), 249-275.

Shaoul, J., Stafford, A., \& Stapleton, P. (2012). Accountability and corporate governance of public private partnerships. Critical Perspectives on Accounting, 23(3), 213-229.

Smith, M., Mathur, N., \& Skelcher, C. (2006). Corporate Governance in a Collaborative Environment: what happens when government, business and civil society work together? Corporate Governance: An International Review, 14(3), 159171.

Spá, P., Voda, P., \& Zagrapan, J. (2018). Does the freedom of information law increase transparency at the local level? Evidence from a field experiment. Government Information Quarterly, 35(3), 408-417.

Suchman, M. C. (1995). Managing Legitimacy: Strategic 
and Institutional Approaches. The Academy of Management Review, 20(3), 571-610.

Swiatczak, M., Morner, M., \& Finkbeiner, N. (2015). How can performance measurement systems empower managers? An exploratory study in state-owned enterprises. International Journal of Public Sector Management, 28(4/5), 371403.

Tolbert, C. J., \& Mossberger, K. (2006). The Effects of EGovernment on Trust and Confidence in Government. Public Administration Review, 66(3), 354-369.

Torres, L., Pina, V., \& Acerete, B. (2006). E-Governance Developments in European Union Cities: Reshaping Government's Relationship with Citizens. Governance: An International Journal of Policy and Administration, 19(2), 277-302. $\begin{array}{ccccc}\text { Transparency } & \text { International } & \text { Spain. } & \text { (2018). } \\ \text { Índice de } & \text { transparencia de las empre- }\end{array}$ sas públicas. https://transparencia.org.es/ indice-de-transparencia-de-las-empresas-publicas-indep-2/ (accessed 5 September 2018).

van der Laan Smith, J., Adhikari, A., \& Tondkar, R. H. (2005). Exploring differences in social disclosures internationally: A stakeholder perspective. Journal of Accounting and Public Policy, 24(2), 123-151.

Wilkinson, P. (2017). 10 Anti-Corruption Principles for State-Owned Enterprises. https://www.transparency.org (accessed 15 November 2017). Transparency International (Ed.).

Wong, W., \& Welch, E. (2004). Does E-Government Promote Accountability? A Comparative Analysis of Website Openness and Government Accountability. Governance, 17(2), 275-297.

World Bank. (2014). Corporate Governance of StateOwned Enterprises. A toolkit. http://documents.worldbank. org/ (accessed 30 October 2017).

Yekini, K. C., Adelopo, I., Andrikopoulos, P., \& Yekini, S. (2015). Impact of board independence on the quality of community disclosures in annual reports. Accounting Forum, 39(4), 249-267. 